\title{
Work-related Musculoskeletal Disorders among Agricultural Workers
}

\author{
Soo-Jin Lee, Hwan Jin Park \\ Department of Occupational and Environmental Medicine, College of Medicine, Hanyang University, Seoul, 133-791
}

\begin{abstract}
This paper describes the current status of musculoskeletal disorders(MSDs) and its ergonomic risk factors, including the preventive intervention in terms of the working conditions and health promotion among agricultural workers. Korean agricultural workers have been exposed to the poor working condition. They have suffered from a variety of work-related injury and diseases more than the general population or the other occupational group. MSDs are one of the most prevalent problems threatening the agricultural worker's health and quality of life. Low back pain, osteoarthritis of hip and knee joint and carpal tunnel syndrome are well known MSDs that was found easily and frequently among agricultural workers. MSDs are worsened by poor ergonomic working conditions such as heavy weight lifting, repetitive movement and awkward posture which involves squatting with long sitting work on the ground, long working hours and heavy workload which are inherent in the greater part of agricultural works. Even though Korean agricultural workers are very weak population in terms of occupational safety and health, no many studies were conducted in the past and no many social and institutional supports were provided sufficiently. We need more interests and efforts in agricultural fields to improve its working condition and to promote health status of agricultural workers.
\end{abstract}

Keywords: Work-related Musculoskeletal Disorders, Ergonomic Risk Factor, Agricultural Workers

\section{Introduction}

작업관련성 근골격계질환(Work-related Musculoskeletal Disorder: 이하 WMSDs)이란 반복적, 지속적 또는 부자 연스러운 작업 자세로 인해 근육이나 조직의 손상이 누적 되어 나타나는 질환으로 허리, 목, 어깨, 팔, 손목 등의 부 위에 주로 나타난다. WMSDs는 1960년에 국제노동기구 (International Labor Organization, ILO)에 의해 작업관련 성 질환의 하나로 인정된 이후, 1980 년대에 미국과 유럽 등 에서 주요 산업보건문제로 대두되었다. 미국의 경우 1999년 에 전체 산업재해자의 약, $1 / 3$ (약, 647,000 명)을 차지하여 이를 관리하기 위해 매년 150 200억 달러의 비용이 지출 되고 있는 실정이다(OSHA, 2000). 우리나라에서도 1996
년도에 WMSDs가 직업병으로 인정된 이래 전체 업무상 질 병 중 WMSDs가 차지하는 비율이 2006년 60.9\%(6,233 명), 2007년 67.3\%(7,723명)로 매우 높아(Ministry of Labor, 2008) 산업안전보건분야에서 아주 중요한 문제로 다루어지고 있다.

농업은 타 산업에 비해 재해 발생률이 높아 광업, 건설업 과 함께 3대 위험산업으로 취급되고 있는데 그 중 WMSDs 가 주목 받고 있다. 농작업의 특성상 수작업이 흔히 이루어 지며 쪼그려 앉거나 허리를 많이 굽힌 상태에서 작업을 하 는 경우가 많다. 이러한 특성 때문에 농업은 근골격계질환 재해율(근로자 100명당 근골격계질환자 수)이 어업(0.29), 제조업 (0.12), 농업(0.09, 사업장 한정)으로 높게 나타나 근골격계질환 관점에서 매우 위험한 직종 중의 하나이며 (Ministry of Labor, 2008) 실제 상당수의 농업인이 근골격

Corresponding Author: Soo-Jin Lee. Department of Occupational and Environmental Medicine, College of Medicine, Hanyang University, Seoul, $133-791$. Mobile: 010-4602-9292, E-mail: sjlee@hanyang.ac.kr

Copyright@2011 by Ergonomics Society of Korea(pISSN:1229-1684 eISSN:2093-8462). All right reserved. 
계질환으로 인해 치료가 필요한 실정이다.

또한, 전체 농어가 인구의 $22.8 \%$ 가 70 세 이상에 이를 정도로 농촌 고령화가 심화되고 있으며(Korea National Statistical Office, 2010), 실제로 65 69세 노인들 중 $80 \%$ 가 여전히 농작업에 참여하고 있는(Rural Resource Development Institute, 2006) 등 농업인에서 타 직업군 에 비해 고령 노동으로 인한 노동부담이 현저히 높은 실정 이다. 그리고 대부분 가족구성원 단위로 운영되어 개별농업 인의 노동부담이 크며 작목별, 농가별의 작업 특성이 다양하 다. 또한, 주작목 외에도 1 2가지 이상 부작목을 겸하는 경 우가 많아 여러 가지 근골격계질환의 위험요인에 동시에 노 출되는 경우가 많다. 소규모로 이루어지는 국내 농작업의 특 성상 기계화가 쉽지 않아 인력에 의한 중량물 취급, 부적절 한 자세 및 반복 작업 등 다양한 인간공학적 위험요인에 노 출되고 있다. 그리고 농번기 등의 특정기간에 신체적 부하가 집중되는 특성 뿐 아니라, 비닐하우스 등의 시설농업의 증가 는 연중무휴 작업으로 인한 노동량의 증가를 초래하고 있다. 여성 인구의 농업참여 비율이 높은데 이 또한 농업인에서
근골격계질환의 위험도를 증가시키는 주요한 위험요소 중 하나이다. 본 연구에서는 농작업에서의 작업관련성 근골격계 질환의 실태와 농작업 위험요소 및 개선 사례들을 정리하여 추후 농업인의 근골격계질환의 예방 - 관리 방향을 제시하고 자 한다.

\section{Prevalence Rate of Musculoskeletal Symptoms Among Agricultural Workers}

농업인의 근골격계증상 유병률에 대한 연구는 과수작목농 업인(Kim et al., 2009), 노지고추농업인 (Kim et al., 2009), 농업인(Kee, 2009), 농축산업종사자(Lee and Lee, 2006), 농업작업자(Kim et al., 2010), 30세 이상 농업종사자(Oh et al., 2001), 시설채소농업인 (Kim et al., 2008), 참외재배 농업인(Bae et al., 2011), 포도재배농업인(Lee et al., 2008) 등에 대해 조사한 사례들이 있다(Table 1).

Table 1. Prevalence rate of musculoskeletal symptoms among agricultural workers

\begin{tabular}{|c|c|c|c|}
\hline Researcher & Object & Method & Result \\
\hline $\begin{array}{l}\text { Kim et al., } \\
(2009)\end{array}$ & $\begin{array}{l}587 \\
\text { Fruit-growers }\end{array}$ & Survey & $\begin{array}{l}\text { - Prevalence rate of musculoskeletal symptom over one body area is } 91.0 \% \text {. } \\
\text { - Prevalence rate over one body area of NIOSH standard } 1 \text { is } 84.2 \% \text {. } \\
\text { - Male farmers: BMI and regular exercise, and physical fatigue are significant variables. } \\
\text { - Female farmers: Regular exercise is a significant variable. }\end{array}$ \\
\hline $\begin{array}{l}\text { Kim et al., } \\
\text { (2009) }\end{array}$ & $\begin{array}{l}155 \text { red pepper } \\
\text { farmers }\end{array}$ & Survey & $\begin{array}{l}\text { - Prevalence rate of musculoskeletal symptom over one body area is } 90.3 \% \text {. } \\
\text { - Prevalence rate over one body area of NIOSH standard } 1 \text { is } 43.9 \% \text {. } \\
\text { - Workload of factors: Climate, Excessive force, Vibration, Dynamic work, Repeated work. }\end{array}$ \\
\hline $\begin{array}{l}\mathrm{Ki} . \\
(2009)\end{array}$ & $\begin{array}{c}84 \\
\text { farmers }\end{array}$ & Survey & $\begin{array}{l}\text { - Prevalence rate over one body area of NIOSH standard } 1 \text { is } 96.4 \% \text {. } \\
\text { - Kind of crop, farming period significantly affect the prevalence rate. }\end{array}$ \\
\hline $\begin{array}{l}\text { Lee et al., } \\
(2006)\end{array}$ & $\begin{array}{l}1,225 \\
\text { farmers }\end{array}$ & Survey & $\begin{array}{l}\text { - Prevalence rate over one body area of NIOSH standard } 1 \text { is } 80.6 \% \text {. } \\
\text { - Female, Main crops and Exposure to Ergonomic risk factor significantly affect the } \\
\text { prevalence rate. }\end{array}$ \\
\hline $\begin{array}{l}\text { Kim et al., } \\
(2010)\end{array}$ & $\begin{array}{l}358 \\
\text { farmers }\end{array}$ & Survey & $\begin{array}{l}\text { - Prevalence rate over one body area of NIOSH standard } 2 \text { is } 18.4 \% \text {. } \\
\text { - Prevalence rate of women is significantly high than man. }\end{array}$ \\
\hline $\begin{array}{l}\text { Oh et al., } \\
(2001)\end{array}$ & $\begin{array}{c}661 \\
\text { farmers }\end{array}$ & Survey & $\begin{array}{l}\text { - Prevalence rate of musculoskeletal symptom over one body area is } 89.0 \% \text {. } \\
\text { - Prevalence rate of women is significantly high than man. } \\
\text { - Men: Less than } 2 \text { people, higher the quality of life, prevalence of musculoskeletal } \\
\text { symptom is significantly high. } \\
\text { - Women: Higher BMI, bad health status, prevalence of musculoskeletal symptom is } \\
\text { significantly high. }\end{array}$ \\
\hline $\begin{array}{l}\text { Kim et al., } \\
(2008)\end{array}$ & $\begin{array}{l}736 \text { greenhouse } \\
\text { vegetable farmers }\end{array}$ & Survey & $\begin{array}{l}\text { - Prevalence rate over one body area is } 94.0 \% \text {. } \\
\text { - Prevalence rate over one body area of NIOSH standard } 1 \text { is } 89.0 \% \text {. }\end{array}$ \\
\hline $\begin{array}{l}\text { Bae et al., } \\
\text { (2011) }\end{array}$ & $\begin{array}{l}217 \text { oriental } \\
\text { melon-growing } \\
\text { farmers }\end{array}$ & Survey & $\begin{array}{l}\text { - Prevalence rate over one body area of NIOSH standard } 1 \text { is } 75.2 \% \text {. } \\
\text { - Female, more than } 30 \text { years of working history, prevalence rate of musculoskeletal } \\
\text { symptom is significantly high. }\end{array}$ \\
\hline $\begin{array}{l}\text { Lee et al., } \\
\text { (2008) }\end{array}$ & $\begin{array}{l}64 \text { vineyard } \\
\text { workers }\end{array}$ & Survey & - Prevalence rate over one body area of NIOSH standard 1 is $73.4 \%$. \\
\hline
\end{tabular}


위 연구들은 모두 설문조사를 통해 이루어졌고 최근 1 년 이내의 각 부위별 자각증상 여부와 미국산업안전보건연구원 (National Institute of Occupational Safety and Health, $\mathrm{NIOSH}$ )에서 사용된 표준화된 설문지를 이용하여 각 부위 별 증상 유병률을 조사하였다(NIOSH, 1993). NIOSH 연구 에서 사용된 기준에 따라 증상이 적어도 1 주일 이상 지속되 거나 한 달에 한 번 이상 반복되는 경우에 해당되는 자를 증 상 호소자로 정의하여 (Hales et al.,1994) 근골격계증상 유 병률을 산출한 경우 과수작목농업인의 유병률은 $84.2 \%$ 이었 으며 (Kim et al., 2009), 노지고추농업인의 유병률은 $43.9 \%$ (Kim et al., 2009), 농업인의 유병률은 96.4\% (Kee, 2009), 농축산업종사자의 유병률은 80.6\% (Lee and Lee, 2006), 시설채소농업인의 유병률은 $89.0 \%$ (Kim et al., 2008), 참외 재배농업인의 유병률은 75.2\% (Bae et al., 2011), 포도재배 농업인의 유병률은 $73.4 \%$ (Lee et al., 2008) 이었다. 증상이 적어도 1 주일 이상 지속되고, 한 달에 한 번 이상 반복되며 통증의 강도는 중간 정도로 느끼는 경우로 정의한 근골격계 증상 유병률은 $18.4 \%$ (Kim et al., 2010)이었다. 여기서 중 간 정도의 통증은 일할 때는 약간 불편하지만, 귀가 후 쉬면 회복되어 불편함이 사라지는 정도의 통증을 의미한다.

한편, 타 직종의 근로자를 대상으로 근골격계증상 유병률 을 조사한 사례들을 보면 일부 제조업체 근로자의 유병률이 23.9\% (Kim and Jeong, 2005), 조선업근로자 59.5\% (Kim et al., 2005), 자동차제조회사근로자 $12.7 \%$ (Kim et al., 2001), 교향악단연주자 79.65\% (Sung et al., 2000), 병원 근로자 66\% (Chu et al., 2007) 등으로 매우 다양하였으나 농업인의 근골격계증상 유병률이 타 직종에 비해 전반적으 로 높다는 것을 알 수 있다.

\section{Ergonomic Risk Factor of Musculoskeletal Disease}

90년대 이후로 농기계가 많이 보급되었지만 새로운 영농 기술이 도입되면서 농한기가 거의 없어지고 농업인구의 급 속한 노령화로 상대적인 노동 강도는 더욱 증가했다고 할 수 있다. 농기계가 보급되어 있는 경우에도 농작업 환경이 적절하게 설계되지 못해 농기계 사용에 많은 제한이 따르는 상황도 흔해서 대부분의 농업인들이 매우 열악한 인간공학 적 위험 환경에 노출되고 있다. 특히 중량물을 취급하는 작 업, 장시간 서 있어야 하는 특수한 작업 환경, 많은 힘을 요 구하는 일, 부적절한 자세, 반복된 동작, 경운기나 트랙터 등 의 농기구의 진동 등이 근골격계질환의 원인이 될 수 있다.

\subsection{Prolonged squatting or bending position}

농작업에 있어서 대표적인 근골격계질환 원인 중의 하나 로 장시간 쪼그리거나 허리를 숙이는 자세를 들 수 있다. 특 히, 쪼그린 상태에서 허리를 60도 내외로 구부리거나 무릎 을 편 상태에서 극단적으로 허리를 구부리는 자세가 문제가 되며 이는 수박, 딸기, 참외 등 대부분의 저상작목 작업들이 이에 해당된다. 참외농업인의 근골격계증상 유병률을 조사한 결과, 허리 $(50.5 \%)$ 가 신체 부위별 유병률 중 가장 높았다. 이는 접목, 모종심기, 순치기, 참외따기 작업에서의 쪼그려 앉 는 자세와 과도한 허리 굽힘으로 인한 것으로 생각된다(Bae et al., 2011). 비닐하우스에서는 참외 외에 오이, 토마토, 딸기, 수박, 호박 등을 재배하는데 대부분의 작물이 키가 작 기 때문에 쪼그려 앉는 자세가 전체 작업의 80 90\%를 차 지한다(Choi et al., 2002). 비닐하우스 내의 대부분의 작업 은 허리를 앞으로 구부린 자세, 무거운 짐을 드는 자세 등으 로 열매 따기, 기둥세우기, 밭매기, 농약살포, 물주기 등을 하는 것이었다(Myung et al., 1993). 오이, 토마토, 딸기 등의 시설채소농업인의 근골격계증상의 부위별 호소율은 허 리 $(76 \%)$ 가 가장 높았으며 질병 유병률은 관절염 및 추간판 탈출증이 가장 높게 나타났는데 이는 이와 같은 시설채소재 배의 농작업 특성과 관련이 있는 것으로 생각된다(Kim et al., 2008) .

또한, 농업인에서 근골격계증상을 유발하는 중요한 위험요 인 중의 하나는 쪼그린 자세라 할 수 있다. 잡초를 뽑거나 농작물을 수확하기 위해 무릎을 굽혀 쪼그리는 자세는 무릎 에 부담을 주며 무릎을 바닥에 끓고 작업하는 자세 역시 무 릎에 접촉스트레스를 주어 근골격계질환을 일으킬 수 있다 (Davis and Kotowski, 2007). 노지고추농업인을 조사한 결 과, 몸통을 약간 구부리는 작업, 오랫 동안 무릎을 구부리거 나 쪼그려 앉아서 하는 작업이 근골격계에 가장 큰 작업부담 을 주는 것으로 나타났다(Kim et al., 2009). 무릎을 굽히 거나 쪼그리고 앉아서 하는 작업을 1 일 2 시간 이상 하는 작업자들에서 2 시간 미만으로 하는 작업자보다 근골격계질 환 발병률이 2.77배 높았다(Kim and Ryu, 2005). 또한 농 촌 여성의 근골격계 유병률을 $\mathrm{X}$-선 촬영과, 증상으로 조사 한 결과 $54 \%$ 로 도시 지역 여성의 유병률보다 매우 높은 결 과를 나타냈다(Seo et al., 2005). 그러나 외국의 연구 결 과에 의하면 농작업이 무릎 골관절염에 영향을 끼쳤을 가능 성이 확실하지 않다고 하는 등(Holmberg et al., 2004) 이 에 대한 연구가 더 필요한 상황이다.

장시간 바닥에 앉아서 작업하는 것 또한 근골격계질환의 위험인자이다. 포도를 선별 - 포장하는 작업의 경우 대부분 수확한 포도바구니를 가져다 놓고 바닥에 앉거나 하우스 근 처의 오두막에서 작업을 하는데 이렇게 바닥에 앉아서 하는 
장시간의 단순반복작업이 신체 전반적인 부분, 특히 허리에 큰 통증을 유발시킨다(Lee et al., 2009).

\subsection{Prolonged looking up position}

사과, 배, 복숭아, 포도 등과 같은 과수작목의 경우, 대부 분의 작업이 머리 위쪽이나 팔을 90 도 이상 올린 자세에서 작업이 이루어지므로 허리, 목, 어깨, 손, 손목 등에 부담을 주게 된다. 사과, 배, 복숭아, 포도, 귤 등을 재배하는 과수 작목농업인의 근골격계증상 호소율은 허리 $(58.8 \%)$, 어깨 (44.6\%), 무릎 $(37.7 \%)$ 순으로 상대적으로 상반신의 유병 률이 더 높게 나타나는 경향을 보인다(Kim et al., 2009).

목 부위는 $20^{\circ}$ 이상의 신전 자세와 목의 최대 굴절상태가 15 분간 지속될 경우 통증을 일으킬 수 있다고 알려져 있다 (Van wely, 1970; Harms-Ringdahl and Ekholm, 1986). 포도작목의 순치기나 알속기 작업은 세밀한 주의력을 요하 며 작업대상의 높이가 다양하기 때문에 작업 중에 목 부위 의 과도한 굴절 $\left(>30^{\circ}\right)$ 이 관찰되는 한편 대부분의 작업에서 목 부위의 굽힘과 젖힘 자세 및 반복적이거나 정적인 자세가 형성되는 것이 관찰되어(Lee et al., 2008) 목, 허리, 어깨, 손, 손목 등에 근골격계질환이 빈번하게 발생한다. 배 재배 작업 또한 높은 작물위치로 위 팔을 들고 목과 허리를 젖히 는 유사한 자세가 지속적으로 이루어지는데 그 중 적과, 봉 지 씨우기, 수확 작업 등에서 가장 높은 근골격계 위험도를 나타냈다(Kim et al., 2005).

\subsection{Heavy work}

중량물 작업은 주로 수확과정과 관계가 깊은데 참외, 수 박 등의 과수작목에서 노출되는 경우가 많다. 특히 수박수 확과정은 $10 \mathrm{~kg}$ 정도 되는 무게를 반복적으로 들고 내리는 작업이 이루어지는데 이는 미국 국립산업안전보건연구원 (NIOSH) 의 중량물 권고 기준을 초과하는 경우가 대부분이 다. 참외작목의 경우 허리에 무리가 되는 과도한 힘을 사용 하는 작업의 비중이 높은 편이다. 그 중 참외수확 · 운반 · 포 장작업은 반복적으로 중량물 (최대 $80 \mathrm{~kg}$ )을 취급하게 되고, 보온덮개 개폐 시에는 적절한 손잡이가 없는 상태로 16 $19 \mathrm{~kg}$ 의 힘을 사용하게 되므로, 시설참외 작업과정에서 허리 에 가장 무리가 간다고 보고하였다(Kim et al., 2006). 사과 과수농업은 농기계의 사용이 어려운 작물인데 그 중 반사필 름작업은 폭 1,000 2,000mm, 길이 500m, 무게 20 40 $\mathrm{kg}$ 의 반사필름을 사과나무 아래 피복하는 작업이다. 보통 2 인 1 조로 수행되며 작업자의 허리 굽힘이 지속적으로 유지 되어 부적절한 작업 자세가 나타나는데 반사필름의 무게로 상완과 전완에 부하가 걸려 피로 누적과 근골격계질환 위험
성이 매우 높다(Lee et al., 2010).

\subsection{Vibration from agricultural machine}

WMSDs의 원인 중 하나가 근로자들이 진동에 노출되어 근육, 혈관, 신경 등에 손상이 누적되는 것이다. 농작업에서 는 농기계 사용 중 전신진동에 노출되는 경우가 많으며 그 중 트랙터와 경운기에서의 농작업이 가장 문제가 되고 있다. 노지고추농업인을 조사한 결과 진동요인에 의한 근골격계 작업부담은 경운기나 트랙터의 잦은 운전에 의한 것이 높게 나타난 바 있다(Kim et al., 2009b). 또한 전신진동은 허리 문제와 명확한 관계가 있으며(Burdorf and Sorock, 1997) 트랙터 운전 시 전신진동과 뒤틀린 자세에 동시에 지속적으 로 노출되어 요통의 위험성이 증가할 수 있다(Toren et al., 2002). 트랙터 운전자와 트랙터를 운전하지 않은 농작업자 사이의 요통 유병률을 코호트 연구로 비교한 결과 트랙터 운전자에서 유의하게 요통 유병률이 높은 결과가 있는 등 (Kumar et al., 1999), 많은 연구들에서 트랙터에 의한 전 신진동과 요통에 관한 연관성이 보고되었다.

\subsection{Hand tool and repeated wrist use}

수작업으로 인한 질환의 가장 중요한 원인은 반복성이 다. 상지의 반복적인 움직임이 누적외상성장해 (cumulative trauma disorders)를 발생시키는 가장 중요한 위험요인이며 누적외상성장해는 수공구를 반복해서 사용하는 작업에서 발 생율이 높은 것으로 알려져 있다. 농작업에서는 과수작목에 서의 열매솎기와 수확 작업 등에서 상지의 반복적인 사용으 로 인한 근골격계질환 가능성이 높다.

포도작목은 순치기 작업인 상지의 수작업이 주를 이루며 손의 반복적인 사용으로 인해 손과 손목의 통증을 호소하는 비율이 41.6\%로 높게 나타났다(Jung and Lee, 2009). 특 히 순치기 작업은 오랜 시간 절단 가위를 사용하므로 손가 락 등의 부위를 지속적으로 압박하게 되고 또한 손목을 반 복적으로 일정 각도 이상 꺾는 자세를 취하게 되어 손목질 환 위험성이 높다.

\section{Prevention and Management of Musculoskeletal Disease}

\subsection{Ergonomic improvement}

\subsubsection{Improvement of transportation}

지금까지 농작업의 기계화가 많이 진행되었으나 작업 특 
성상 기계화가 어려운 농작업은 아직 인력에 의존하고 있어 특정한 신체 부위의 반복 작업, 불편한 작업 자세, 무리한 힘 등의 근골격계질환 위험요소가 여전히 존재하고 있다. 그 중 시설과 채수 작업은 특성상 좁고 밀폐된 공간에서의 부적절 한 자세로의 작업 및 불완전하고 긴 통로, 무거운 중량물의 반복적인 작업 등으로 인해 근골격계질환의 위험에 많이 노 출되고 있는 실정이다.

시설참외재배는 대부분 비닐하우스 내부에서 작업을 수행 하는데 노동집약적인 특성을 가지고 있으며 여러 가지 형태 의 작업이 존재하는데 그 중 운반 작업이 가장 많은 동작을 필요로 하고, 가장 노동 강도가 센 작업이다. 다량의 수확물 은 많은 중량물 작업과 쪼그려 앉은 자세의 작업 및 긴 운반 통로 내에서의 운반 작업을 필요로 하여 이를 개선하기 위한 운반차량에 대한 연구가 많이 수행되어 왔다. 외발식 수확운 반차는 가격이 저렴하고 고량이 좁은 곳에서도 운행할 수 있어 많이 사용 중이나 균형 유지가 어려워 여성과 노약자는 사용하기가 어려운 단점이 있다. 레일식 수확운반차는 천장 에 설치한 레일을 따라 수동으로 작동하여 현재 가장 편한 운반장치로 인정받고 있으나 비용이 비싸고 천장에 별도의 시설이 필요하며 다른 고랑 및 시설로의 이동이 불편한 단점 이 있다(Kim et al., 2006). 참외운반 작업의 인간공학적 위 험요인을 개선하기 위해 참외운반차량에 대한 많은 연구들 이 있었는데 $\operatorname{Kim}(2008)$ 은 참외 수확운반차의 손잡이, 바 퀴, 브레이크, 적재부를 개선한 새로운 운반차량을 개발하였 다. 새로 제작한 운반차량을 이용하여 작업을 수행한 결과 허리에 가해지는 부하가 감소하고 $\mathrm{REBA}$ 점수의 감소, 심박 수, 산소 소비량 등이 감소하는 등 인체에 가해지는 부하가 줄어드는 연구 결과를 보였다. Lee et al.(2008)은 횡간 손 잡이를 제작하고 보조바퀴 및 브레이크, 적재부 등을 개선한 수확운반차량을 개발하였다. 개발한 운반차량으로 작업한 결
과 $\mathrm{REBA}$ 점수가 크게 개선되었고 들기, 밀기 동작 등에서 작업부하가 감소하는 효과가 있었다.

고추수확 및 운반 작업 역시 장시간 작업과 쪼그리고 허리 를 구부리는 자세에서의 작업 및 2 30kg 이상의 중량물을 긴 통로를 통해 운반해야 하는 등 많은 노동력을 필요로 한 다. Ahn et al. (2002)은 고추를 따면서 계속해서 포대를 들 어 옮겨야 하는 불편을 없애기 위해 포대를 들지 않고 밀면 서 수확할 수 있도록 하는데 중점을 둔 수확운반차량을 개발 하였다. 그리고 1 회 운반 시 3 4회 고추포대를 동시에 운반 가능하고 앉아서 수확할 수 있도록 의자를 설치한 형태의 대형 수확운반차량을 개발하였다. 새로 개발한 수확운반차량 으로 작업한 결과 고추수확 및 운반 작업의 문제점으로 지적 되었던 중량물 취급과 손가락 잡는 힘의 위험요인이 개선되 는 것으로 나타났다.

천장레일형 운반장치로 인간공학적 위험요인 개선을 시도 한 연구도 있다. Jung et al.(2009)은 오이, 토마토, 고추 등 의 시설농가에 높낮이 조절 기능, 받침대 확장, 받침대 하부 의 지지대를 보강하고 레일바퀴 재질을 개선하여 안전성을 보강한 천장레일형 운반장치를 설치하여 개선사항을 관찰하 였다. 그 결과 중량물을 들어 옮기는 작업이 단순한 밀기 작 업으로, 쪼그려 앉아 수확하던 자세가 의자에 앉아 작업하는 자세로 개선되었고 작업시간 감축 및 피로자각증상의 감소 효과가 있었다.

\subsubsection{Improvement of harvesting and boxing}

현재 농촌에서의 수확 및 포장 작업은 대부분 고령 및 여 성 농업인에 의해 이루어지고 있지만 고령자와 여성의 신체 적 특성을 고려한 작업장비의 개발이 부족하여 근골격계질 환에 대한 위험성이 증가하고 있는 상황이다. 따라서 농작업 의 편이성을 증가시키고 여러 인간공학적 위험요인을 개선

Table 2. Improvement of transporting system in agricultural activity

\begin{tabular}{c|c|c|l}
\hline Researchers & Crops & Details & \multicolumn{1}{c}{ Measure of working improvement and result } \\
\hline $\begin{array}{c}\text { Ahn et al., } \\
(2002)\end{array}$ & Red pepper & $\begin{array}{c}\text { Harvesting and } \\
\text { transporting }\end{array}$ & $\begin{array}{l}\text { - Developing small and large harvesting and transporting vehicle. } \\
\text { - Improvement of risk factors: Heavy handling and finger grip force. }\end{array}$ \\
\hline $\begin{array}{c}\text { Kim et al., } \\
(1997)\end{array}$ & $\begin{array}{c}\text { Bare ground vegetables } \\
\text { (welsh onion) }\end{array}$ & $\begin{array}{c}\text { Trim, } \\
\text { transporting }\end{array}$ & - Chair and vehicle attaching roller wheel. \\
\hline $\begin{array}{c}\text { Jung et al., } \\
(2009)\end{array}$ & $\begin{array}{c}\text { Greenhouse vegetables, } \\
\text { greenhouse fruits }\end{array}$ & $\begin{array}{c}\text { Harvesting and } \\
\text { transporting }\end{array}$ & $\begin{array}{l}\text { - Ceiling rail carrier. } \\
\text { - Reducing repeated handling heavy work, work risk, and improvement } \\
\text { of fatigability. }\end{array}$ \\
\hline $\begin{array}{c}\text { Kim } \\
(2008)\end{array}$ & Oriental melon & Transporting & $\begin{array}{l}\text { - Development of transporting vehicle. } \\
\text { - Decrease the work load on arm, shoulder, waist. } \\
\text { - Decrease REBA score of the upper limb, work load. }\end{array}$ \\
\hline $\begin{array}{c}\text { Lee et al., } \\
(2008)\end{array}$ & $\begin{array}{c}\text { Greenhouse } \\
\text { oriental melon }\end{array}$ & $\begin{array}{c}\text { Harvesting and } \\
\text { transporting }\end{array}$ & $\begin{array}{l}\text { - Development of electric harvesting drive vehicle. } \\
\text { - Decrease the work load on the body, neck, lower limb, arm and wrist. } \\
\text { - Decrease REBA score on lifting and down. }\end{array}$ \\
\hline
\end{tabular}


Table 3. Improvement of harvesting and boxing works in agricultural activity

\begin{tabular}{c|c|c|l}
\hline Researchers & Crops & Details & \multicolumn{1}{c}{ Measure of working improvement and result } \\
\hline $\begin{array}{c}\text { Lee et al., } \\
(2009)\end{array}$ & Grape & $\begin{array}{c}\text { Packing and } \\
\text { selection }\end{array}$ & $\begin{array}{l}\text { - Selection and work table, transporting cart. } \\
\text { - Decrease of heart rate, RULA score, REBA score, spine risk and improvement of } \\
\text { OWAS score. } \\
\text { - Improvement of working efficiency and reducing physical load. }\end{array}$ \\
\hline $\begin{array}{c}\text { Ha et al., } \\
(2009)\end{array}$ & Strawberry & Packing & $\begin{array}{l}\text { - Multi-layer rotating worktable. } \\
\text { - Improvement of REBA score. } \\
\text { - Shortening of working time and improvement of productivity. }\end{array}$ \\
\hline $\begin{array}{c}\text { Oh et al., } \\
(2008)\end{array}$ & Shiitake & Harvesting & $\begin{array}{l}\text { - Development of ceiling rail harvesting and transporting vehicle. } \\
\text { - Decrease REBA score of when harvesting and harvesting time. }\end{array}$ \\
\hline
\end{tabular}

하여 고령 및 여성 농업인이 효율적으로 농작업에 참가하여 생산성을 높일 수 있는 장비 개선이 필요하다.

Oh et al. (2008)에 의하면 표고버섯시설재배의 경우 주로 여성 작업자가 수확을 하는데 고랑의 폭이 극히 좁고 표고버 섯 한 바구니는 7 8kg에 달해 바구니를 들면서 수확 작업 을 하기가 매우 어렵다. 이를 개선하기 위해 천장레일형 수 확운반장치를 개발하여 현장에 적용한 결과 버섯 하단부 수 확 작업의 $\mathrm{REBA}$ 점수가 절반으로 감소하였으며 작업시간 및 시설 내부 이동시간 역시 절반 이상 단축되는 효과가 있 었다.

또한 농업의 기계화로 인해 육체적 부담이 점점 감소하고 있음에도 불구하고 과수의 포장 및 선별 작업은 불편한 작업 자세로 수행되는 경우가 많고 반복적인 중량물 들기 작업 등 을 해야 하므로 인간공학적 개선이 필히 필요한 부분이다. Lee et al. (2009)은 포도농가의 포장 및 선별 작업의 작업 개선을 위하여 포장작업자의 신체치수에 맞추어 높이 조절 이 가능한 작업대와 안내롤러로 가볍게 밀어도 이송이 수월 한 운반수레를 도입하였다. 새로운 장비를 도입한 결과 심박 수 감소, OWAS, RULA 점수 감소, 주관적인 불편도 증상 감소 및 척추 Risk가 감소하는 효과가 있었다.

딸기선별 및 포장 작업 역시 여성 및 고령작업자들이 불편 한 자세에서 장시간 작업을 수행하는 고 위험작업이다. $\mathrm{Ha}$ et al.(2009)은 반복적으로 앉기, 일어나기, 쪼그려 앉기, 허 리 숙임 등의 동작이 발생하는 딸기포장작업 개선을 위해 다 층형 회전작업대를 개발하였다. 새로 개발한 작업대를 사용 한 결과 REBA 점수가 크게 개선되었으며 수확바구니의 이 동 및 포장, 박스 작업의 시간이 단축되어 생산성 향상에 효 과가 있었다.

\subsubsection{Improvement of other work}

과수농업은 일반농업에 비해 지형 및 재배지의 모양이 불 규칙하고 상대적으로 농경지 면적이 작은 경우가 많아 기계 화가 더디게 진행되었다. 또한 과수종류가 다양하고 과수종
류에 따른 재배 환경 및 방법이 다양하여 기계화가 어려운 특징이 있다. 그러나 인구가 증가하고 경제 수준이 상승함에 따라 과수 수요가 증가하고 이로 인해 재배 면적 또한 늘어 나고 있는 추세로 기존에 많이 사용하고 있는 운반차, 선별 기, 관리기 이외에 작업부하를 경감시키기 위한 자동화 기계 에 대한 관심이 증가하고 있다(Lee et al., 2010). 그 중 사 과농업은 대부분 산악지형에서 이루어지고 경사지와 불규칙 한 지형이 많아 농기계 사용이 어려운 특성이 있다. 사과반 사필름 작업은 허리 굽힘 자세와 중량물 취급이 많아 근골 격계질환의 위험성이 매우 높은 작업이다. Lee et al.(2010) 은 손잡이를 개선하고 동력장치를 부착한 필름 피복기를 개 발하여 OWAS, RULA, REBA 점수개선 및 작업시간단축 등의 인간공학적 위험요인의 개선을 시도한 바 있다.

포도재배 역시 근골격계질환 유병률이 매우 높은 농작업 중의 하나이다. 경사지에서 재배하는 경우가 많아 엉거주춤 한 자세 등의 근골격계질환 위험요인이 있고 작업의 특성상 연중 서서 작업을 하게 된다. 그 중 순치기 작업과, 알속기 작업은 장시간의 반복적인 상지의 수작업이 필요해 목, 어깨, 손목, 손 등에 부담을 주는 작업으로 이에 대한 시급한 개선 책이 필요한 상황이다. Chae et al. (2010)은 손잡이의 각도 와 가동날 등을 개선한 전동 가위를 개발하였는데 이를 통 해 손에 가해지는 압력이 감소하고 손작업 자세가 개선되는 효과가 있었다. 또한 주관적 불편도가 적은 것으로 나타나 전반적인 작업부하를 감소시키는데 도움이 되었다. Kim et al. (2009)은 작업자가 편안한 상태로 좌, 우로 이동하면서 순치기 작업을 수행할 수 있도록 레일 이동형 작업의자를 개발하였는데 서서 하는 순치기 작업에 비해 목, 어깨, 허리 부위의 RULA, REBA 점수 개선이 있었고 목과 어깨의 주 관적 불편도 개선 효과가 있었다.

Kim et al.(2009)은 기존에 시판되고 있는 알솎기 작업의 자를 이용하여 작업개선효과를 평가하였다. 작업의자를 이용 하여 알속기 작업을 한 경우 기존의 방식에 비해 심박수 및 산소소비량을 줄여 줄 뿐만 아니라 주관적인 노동 강도 또 
Table 4. Improvement of other agricultural works

\begin{tabular}{c|c|c|c}
\hline Researchers & Crops & Details & \multicolumn{1}{c}{ Measure of working improvement and result } \\
\hline $\begin{array}{c}\text { Lee et al., } \\
(2010)\end{array}$ & Apple & $\begin{array}{c}\text { Reflective } \\
\text { film }\end{array}$ & $\begin{array}{l}\text { - Development of reflective film machine. } \\
\text { - Improvement of ergonomic risk, Decrease worker's fatigue, Improvement work } \\
\text { efficiency and productivity. }\end{array}$ \\
\hline $\begin{array}{c}\text { Chae et al., } \\
(2010)\end{array}$ & Grape & Pinching & $\begin{array}{l}\text { - Development of electric scissors. } \\
\text { - Decrease pressure of hand, workload, subjective inconvenience. }\end{array}$ \\
\hline $\begin{array}{c}\text { Kim et al., } \\
(2009)\end{array}$ & Grape & Pinching & $\begin{array}{l}\text { - Development of rail working chair. } \\
\text { - Decrease of RULA, REBA score than standing position and subjective } \\
\text { inconvenience, improvement of heart rate. }\end{array}$ \\
\hline $\begin{array}{c}\text { Kim et al., } \\
\text { (2009) }\end{array}$ & Grape & Thinning & $\begin{array}{l}\text { - Thinning chair. } \\
\text { - Decrease heart rate, oxygen consumption, emotional burden. } \\
\text { - Decrease of subjective work load. }\end{array}$ \\
\hline $\begin{array}{c}\text { Jung et al., } \\
(2007)\end{array}$ & Farming & Squatting & $\begin{array}{l}\text { - Establishing proper height of work table. } \\
\text { - Decrease of musculoskeletal disease of waist, shoulder, lower limb and } \\
\text { improvement of productivity. }\end{array}$ \\
\hline $\begin{array}{c}\text { Ministry for food, } \\
\text { and fishers (2010) }\end{array}$ & Combine & $\begin{array}{l}\text { - Development of combine for farmer's convenience and safety. } \\
\text { - Improvement of convenience by analyzing load on lumbar spine. } \\
\text { - Improvement of vibration character. }\end{array}$ \\
\hline
\end{tabular}

한 낮춰 주는 것으로 평가하였다.

\subsection{Management program of musculoskeletal disease}

우리나라의 전국 농가 인구는 1990년 666만 명에서 2000년 403만 명, 2003년 353만 명으로 절대적인 수는 감소하고 있다(Ministry for Food, Agriculture, Forestry and Fisheries., 2009). 도시 지역의 65세 이상 인구 비율 은 2000년 5.5\%에서 2005년 $7.2 \%$ 로 증가하는데 그친 반면 농촌 지역은 $14.7 \%$ 에서 $18.6 \%$ 로 늘어나 도시 지역 에 비해 고령화가 급속히 진행되고 있다(Korea National Statistical Office, 2006). 연령이 증가하면서 근육의 양이 감소하여 기능이 저하되고 관절의 연골에도 퇴행성 변화를 일으켜 관절염으로 통증 및 운동제한이 생기게 된다. 또한 골조직은 골 흡수가 골 형성을 능가하여 골다공증으로 인한 골절 가능성이 커지게 된다(Chang, 2005). 게다가 농촌 지 역의 노인들은 특정 작업에 수십 년간 누적 노출되었고 근 골격계질환 예방에 대한 의식이 부족한 경우가 많다. 그러므 로 예방적 차원의 프로그램과 개인의 예방의식을 고취시키 는 것이 매우 중요하다(Yang, 2010). 근골격계질환은 특성 상 예방 및 관리를 통해 통증을 완화하고 기능을 향상시킬 수 있다. 그러므로 꾸준히 예방적 프로그램을 적용할 필요가 있으며 이에 대한 연구 결과들이 많이 보고되었다.

Kwon et al.(2008)은 포도재배농업인 57명을 대상으로 9 번의 근력 및 유연성 강화교육을 실시하고 중간에 3 번의 근골격계질환, 근골격계통증, 근골격계근력 및 유연성 평가
를 하였다. 프로그램을 실시한 결과 통증 점수는 유의하게 감소하였으며 근력 및 유연성 항목이 유의하게 성적이 증가 하였다.

Kang and Sung(2010)은 농촌 지역의 65세 이상 노인 39 명을 저항성 운동과 걷기 집단 13 명, 에어로빅과 요가 집 단 13 명, 통제 집단 13 명으로 나누어 12 주간 주 3 회, 일일 60 분씩 해당된 운동을 실시하였다. 프로그램을 실시한 결과 저항성 운동과 걷기의 병행 운동 시 상완근지구력, 협응성, 유연성, 민첩성, 정적 · 동적평형성, 보행능력이 향상되어 에 어로빅과 요가에 비해 일상생활체력의 향상에 효과적인 것 으로 나타났다. 노인들의 경우 노화가 진행됨에 따라 유연성, 평형성, 순발력 등이 저하되고 특히 70대에 이르면 근력, 근지구력, 그리고 민첩성이 크게 감소되어 근골격계질환의 위험성에 더 크게 노출되기 쉽다. 이에 Han and Lee(2008) 는 노인을 대상으로 8주간 유산소, 근력, 평형성 운동의 복 합 운동을 실시하였다. 그 결과 근력, 근지구력, 민첩성, 평 형성, 유연성, 그리고 보행능력이 향상되었다고 보고하였다. O et al.(2010)은 16주간 주 3회 저항 및 평형성 운동을 실시한 결과 근력 및 근지구력, 심폐지구력, 평형성 등에서 유의한 개선 효과가 있었다고 보고하였다.

이러한 연구 결과들은 근골격계질환 관리프로그램으로서 운동이 효과가 있다는 것을 보여주고 있다. 참여자들이 프로 그램 종료 후에도 지속적으로 근력 및 유연성 강화 운동을 한다면 근골격계질환으로 인해 발생한 통증을 관리하고 예 방하는데 도움이 될 것이다(Kwon et al., 2008). 또한 노 인기에 나타나는 근력 감소 등의 신체 변화는 근골격계질환 
Table 5. Prevention programs for musculoskeletal disorders in rural area

\begin{tabular}{c|c|c|c}
\hline Researcher & Object & \multicolumn{1}{|c}{ Method } & \multicolumn{1}{c}{ Result } \\
\hline $\begin{array}{c}\text { Kwon et al., } \\
(2008)\end{array}$ & $\begin{array}{c}57 \text { grape } \\
\text { farmers }\end{array}$ & $\begin{array}{c}\text { - Nine muscular power and flexibility } \\
\text { strengthening education. } \\
\text { - Three assessment between strengthening } \\
\text { education. }\end{array}$ & $\begin{array}{l}\text { - Decrease pain. } \\
\text { - Improvement of muscular power and flexibility. }\end{array}$ \\
\hline $\begin{array}{c}\text { Kang et al., } \\
(2010)\end{array}$ & $\begin{array}{c}\text { 39 people more } \\
\text { than } 65 \text { years of } \\
\text { rural area }\end{array}$ & $\begin{array}{c}\text { - Conducting complex program of } \\
\text { resistance exercise, walking, aerobic } \\
\text { and yoga for 12 weeks. }\end{array}$ & $\begin{array}{l}\text { - Improvement of brachial muscle endurance, } \\
\text { coordination, flexibility, agility, balance, } \\
\text { walking ability. } \\
\text { - Resistant exercise and walk are of help } \\
\text { to improvement of life stamina than aerobic } \\
\text { and yoga. }\end{array}$ \\
\hline $\begin{array}{c}\text { Han et al., } \\
(2008)\end{array}$ & $\begin{array}{c}15 \text { people more } \\
\text { than } 68 \text { years of } \\
\text { rural area }\end{array}$ & $\begin{array}{c}\text { - Conducting complex program of } \\
\text { aerobic, muscular, balance exercise. }\end{array}$ & $\begin{array}{l}\text { - Significant improvement of grasping power, } \\
\text { muscular power of lower limb, agility, } \\
\text { balance, flexibility, walking ability. }\end{array}$ \\
\hline $\begin{array}{c}\text { O et al., } \\
(2010)\end{array}$ & $\begin{array}{c}\text { 28 people more than } \\
65 \text { years of rural } \\
\text { area and 27 people } \\
\text { of control group }\end{array}$ & $\begin{array}{c}\text { - Three times a week, conducting } \\
\text { resistance and balance exercise } \\
\text { for 16 weeks. }\end{array}$ & $\begin{array}{l}\text { - Significant improvement of muscular power } \\
\text { and stamina, cardiopulmonary endurance, } \\
\text { balance. }\end{array}$ \\
\hline
\end{tabular}

의 중요한 위험요소로 저항 운동과 근력 운동이 신체 기능 향상 및 삶의 질 개선, 더 나아가 근골격계질환 예방 및 악 화방지에 중요한 효과를 나타낼 수 있다. 그러나 아직까지는 농촌 지역의 노인을 위한 맞춤식 운동프로그램이 매우 부족 한 현실이며 추후 각 지역별, 작목 별로 노인의 특성을 고려 한 다양한 맞춤식 운동프로그램 개발과 보급이 필요하다.

\section{Conclusion and Discussion}

본 연구는 농업인의 근골격계질환의 실태와 관련된 인간 공학적인 위험요인들을 고찰하였으며 또한 근골격계질환 예 방 - 관리를 위해 국내에서 시도된 다양한 인간공학적 개선 및 운동프로그램 시행 사례들을 분석함으로써 이들의 효과 에 대해 정리하였다.

많은 연구들이 타 직종에 비해 농업인의 근골격계문제가 보다 심각하다는 것을 보여주고 있으며 이의 원인으로 열악 한 농작업 환경을 지목하고 있다.

근골격계질환과 관련된 농작업에 내재된 대표적인 인간공 학적 위험요인들은 장시간 쪼그려 앉거나 허리를 구부리는 자세, 장시간 올려다 보는 작업 자세 등의 부적절한 자세를 동반하는 작업들이다. 또한 중량물 취급작업, 농기계에 의한 진동, 수공구 사용과 손목의 반복적인 사용 등을 들 수 있다. 열악한 농작업 환경을 개선하고 인간공학적 위험요인을 경감하기 위해 운반장치, 운반차량, 작업의자, 작업대 등에 대한 개선 사례와 농촌 노인들의 근골격계질환 예방 및 관
리를 위해 지역사회 중심으로 일부 운동프로그램들이 시도 된 사례들을 통해 농기계에 대한 인간공학적 개선과 건강증 진프로그램들이 농업인의 근골격계질환 예방에 매우 효과적 이라는 결과를 확인할 수 있었다. 그러나 연구된 사례가 매 우 적고 소수의 연구자들에 의해 일부 농작업 영역에 제한 적으로 수행된 점 등으로 인해 농업 전반에 적용하기에는 해결해야 할 과제가 너무도 많은 실정이다. 향후 보다 다양 한 농업인과 농작업을 대상으로 관련 연구들이 진행되어야 할 것이다.

지금도 대부분의 농업인들이 매우 열악한 농작업 환경에 노출되고 있고 다양한 근골격계질환으로 고통을 격고 있다. 산업안전보건 측면에서 농업인들은 매우 취약한 집단임에도 불구하고 이들에 대한 연구, 사회적 및 정부 차원의 관심과 지원이 매우 부족한 실정이다. 향후 농작업 환경을 개선하고 농업인의 건강을 증진시키기 위한 노력이 절실히 필요하다.

\section{References}

Ahn, O. S., Lee, K. S., Kim, K. R. and Lee, H. K., "Developing transport vehicle to improve red pepper harvesting and transporting", Proceedings of 2002 13th Spring Conference of the Korean Journal of Community Living Science, pp.129-131, 2002.

Bae, K. J., Lee, K. S., Kong, Y. K., Oh, K. J. and Lee, S. J., The Prevalence of Musculoskeletal Symptoms and the Ergonomic Risk Factors among Oriental Melon-growing Farmers, Korean Journal of Occupational and Environmental Medicine, 23(1), 1-8, 2011. 
Burdorf, A. and Sorock, G., Positive and negative evidence of risk factors for back disorders, Scandinavian Journal of Work and Environmental Health, 23(4), 243-256, 1997.

Chae, H. S., Kim, K. W., Lee, K. S., Kim, C. H., Lee, K. M., Choi, Y. W. and Park, K. S., The Study on the Moving Rail-chair and Electromotive Scissors for Preventing of the Musculoskeletal Disorders, Journal of the Ergonomics Society of Korea, 29(1), 139-144, 2010.

Chang, J. S., Senile Musculoskeletal Disorder, Journal of the Korean Medical Association, 48(3), 247-253, 2005.

Choi, J. W., Kim, M. J. and Lee, J. Y., Evaluation of the Farmers' Workload and Thermal Environments during Cucumber Harvest in the Greenhouse, Journal of Korean Society of Living Environmental System, 9(3), 245-253, 2002.

Chu, S. H., Kim, I. A. and Lee, S. J., "Related factors of musculoskeletal symptoms in a hospital, women workers", Proceedings of 39th Fall Conference of Korean Society of Occupational and Environmental Medicine, pp.463-464, 2007.

Davis, K. G. and Kotowski, S. E., Understanding the ergonomic risk for musculoskeletal disorders in the United States agricultural sector, American Journal of Industrial Medicine, 50(7), 501-511, 2007.

Ha, W. H., Park, S. H., Yu, Y. H. and Lee, H. N., "Development of a Multi-Layered Rotating Table for Strawberry Sorting and Packing", Proceedings of 2009 Conference of Korea Industrial and Systems Engineering, 3, pp.179-182, 2009.

Hales, T. R., Sauter, S. L., Peterson, M. R., Fine, L. J. Putz-Anderson, V., Schleifer L. R., Ochs, T. T., and Bernard, B. P., Musculoskeletal disorders among visual display terminal users in a telecommunications company, Ergonomics, 37(10), 1603-1621, 1994.

Han, Y. S. and Lee, S. J., Effects of Combined Exercise Program for 8 Weeks on Physical Fitness in Elderly Farmers, The Korean Journal of Growth and Development, 16(4), 313-318, 2008.

Harms-Ringdahl, K. and Ekholm, J., Intensity and character of pain and muscular activity levels elicited by maintained extreme flexion position of the lower-cervical-upper-thoracic spine, Scandinavian Journal of Rehabilitation Medicine, 18(3), 117-126, 1986.

Holmberg, S., Thelin, A. and Thelin, N., Is there an increased risk of knee osteoarthritis among farmers? A population-based case-control study, International archives of occupational and environmental health, 77(5), 345-350, 2004

Jung, B. Y., Kim, Y. H., Kim, S. K. and Kim, K. H., "Improving example of transporting system of geenhouse farm", Proceedings of 2009 Spring Conference of Ergonomics Society of Korea, pp.149-152, 2009.

Jung, H. N. and Lee, I. S., "Survey of the musculoskeletal disorders of grape farmers", Proceedings of 2009 Spring Conference of Ergonomics Society of Korea, pp.200-203, 2009.

Jung, I. J. and Jung, H. S., Verification of Suitable Height of Plank Seat for Improving the Health and Safety of Farmers, Journal of the Korea safety management and science, 9(4), 11-16, 2007.

Kang, C. K. and Sung, S. C., Effects of two kinds of combined exercise training on daily living fitness in elderly farmers, Korean Journal of Sport Science, 21(2), 1152-1164, 2010.
Kee, D. H., Survey of Musculoskeletal Disorders for Farmers, Journal of the Korean Society of Safety, 24(3), 59-64, 2009.

Kim, H. J. and Jeong, W. C., Symptom Prevalence and Primary Intervention of Work-related Musculoskeletal Disorders and Their Related Factors Among Manufacturing Workers, Korean Journal of Occupational and Environmental Medicine, 17(2), 116-128, 2005.

Kim, I. R., Kim, J. Y., Park, J. T., Choi, J. W., Kim, H. J. and Yeon, Y. T., The Relationship between psychosocial stress and Work-related Musculoskeletal Symptoms of Assembly Line Workers in the Automobile industry, Korean Journal of Occupational and Environmental Medicine, 13(3), 220-231, 2001.

Kim, K. R., Choi, J. W., Lee, K. S. and Song, E. Y., Health Condition and Work-related Musculoskeletal Disorders in Greenhouse Vegetable Farmers, Journal of Korean Society of Occupational and Environmental Hygiene, 18(1), 49-61, 2008.

Kim, K. R., Lee, K. S., Kim, H. C., Ko, E. S. and Song, E. Y., Health Condition and Musculoskeletal Disorders (MSDs) in Fruit-growers, Korean Journal of Community Living Science, 20(1), 5-17, 2009.

Kim, K. R., Lee, K. S., Kim, H. C. and Song, E. Y., Health Status and Musculoskeletal Workload of Red Pepper Farmers, Journal of the Ergonomics Society of Korea, 28(3), 7-15, 2009.

Kim, K. R., Lim, D. S., Lee, K. S., Kim, H. C. and Chae, H. S. "Evaluation of physiological burden of grape cluster thinning using working chair", Proceedings of 2009 Spring Conference of Ergonomics Society of Korea, pp.295-299, 2009.

Kim, K. S., Kim, K. R., Kim, H. C., Lee, K. S. and Jung, S. H., "The Musculoskeletal Risk levels and Intervention plan of the high risk tasks in pear, red pepper and yellow melon farmers", 2005 Spring Conference of The Korean Journal of Community Living Science, pp.203-204, 2005.

Kim, K. S., Kim, K. R., Kim, H. C. and Lee, K. S., Risk Assessment and Symptoms of Musculoskeletal Disorders in Melon Farm Workers, Journal of Korean Society of Occupational and Environmental Hygiene, 16(4), 385-397, 2006.

Kim, K. W., Chae, H. S. and Lee, K. S., "The Study on the Improvement of Grape Heading Work through Working Chair of Rail-Drift", Proceedings of 2009 Spring conference of Ergonomics Society of Korea, pp.145-148, 2009.

Kim, S. W., Sohn, A. R. and Lee, J. S., The Effects of Job Stress on Musculoskeletal Diseases Among Shipyard Workers, Journal of Korean Academy of University Trained Physical Therapists, 12(3), 1-10, 2005.

Kim, Y. C. and Ryu, Y. S., Ergonomic Evaluation of The Hazardous Jobs in Squatting Work Posture, Journal of the Ergonomics Society of Korea, 24(1), 37-41, 2005.

Kim, Y. C., Shin, Y. S, Kim, D. S. and Hong, C. W., "The gender difference in Agriculture Workers survey of Work-Related Musculoskeletal Disorders", Proceedings of 2010 Fall Conference of Ergonomics Society of Korea, pp.94-98, 2010.

Kim, Y. H., Development of an ergonomic vehicle for melon farm, Master's thesis of Sungkyunkwan University, 2008

Korea National Statistical Office, Report of population and housing census, 
2006.

Korea National Statistical Office, Agriculture and Fisheries Survey 2009, 2010.

Kumar, A., Varghese, M., Mohan, D., Mahajan, P., Gulati, P. and Kale, S., Effect of Whole-Body Vibration on the Low Back: A Study of Tractor-Driving Farmers in North India, Spine, 24(23), 2506, 1999.

Kwon, S. C., Ryou, H. C., In, H. K., Lee, K. S. and Lee, S. J., Effect of the Prevention Programs for Musculoskeletal Disorders in one Farming Village, Journal of Agricultural Medicine and Community Health, 33(1), 1-10, 2008.

Lee, C. M., Yoo, B. C., Sin, K. H., Park, M. S., Lee, S. W. and Shin, O. H., "Development of Reflective film machine for Prevent Musculoskeletal Diseases. -Apple orchard agriculture-", Proceedings of 2010 Fall Conference of Ergonomics Society of Korea, pp.290-293, 2010.

Lee, K. S., Kim, K. W., Kim, H. C., Chae, H. S., Jung, C. E., Mok, M. J., Han, S. R. and Park, K. S., "The Study of Grape Selecting and Packing Work Improvement", Proceedings of 2009 Fall Conference of Ergonomics Society of Korea, pp.222-233, 2009.

Lee, K. S., Kim, K. W., Choi, H. S., Kim, C. H., Nam, S. Y, Lee, K. M., Choi, Y. W. and Park, K. S., Evaluation of Convenience Equipment for Improve Work Efficiency and Preventing of Farm Work-Related Musculoskeletal Disorders, Journal of the Ergonomics Society of Korea, 29(4), 495-503, 2010.

Lee, S. J. and Lee, K. S., "Prevalence of agricultural-related musculoskeletal disorders and ergonomic risk factors", Proceedings of 31th Health Conference of Korean Society for Health Education and Promotion, pp.11-13, 2006.

Lee, S. S., Kim, Y. H., Choi, A. R. and Mun, J. H., A Study on Ergonomics Design of Wheelbarrow for Melon Farm on Protected Horticulture, Journal of Biosystems Engineering, 33(3), 157-166, 2008.

Lee, Y. H., Lee, J. H., Lee, K. S., Kim, K. R. and Lee, S. J., Ergonomic risk factors related to musculoskeletal symptoms in the vineyard workers, Journal of Korean Society of Occupational and Environmental Hygiene, 18(2), 122-132, 2008.

Ministry for Food, Agriculture, Forestry and Fisheries, Statistical Yearbook of Agriculture and Forestry, 2009.

Ministry for Food, Agriculture, Forestry and Fisheries, Development of combine cabin for farmer's safety and convenience, 2010.

Ministry of Labor, Analysis of Industrial Accidents 2007, 2008.

Myung, J. Y., Shim, H. S. and Choi, J. W., Transactions: A Study of Development of Work Wear for the Plastic House Workers, Journal of the Korean Society of Clothing and Textiles, 17(1), 19-35, 1993.

National Institute of Occupational Safety and Health(NIOSH), NIOSH health hazard evaluation report, NIOSH report No. PB 93-188-456, 1993.

O, Y. S. and Park, W. Y., The effect of the complex exercise program for fitness, Sensory organization and motor control function development in agriculture old adults, Journal of Korean Society of Sport and Leisure Studies, 42(2), 825-836, 2010.
Occupational Safety and Health Administration(OSHA), National occupational illness by category of illness, private industry: U.S., 2000.

Oh, H. O., Kam, S., Han, C. H., Hwang, B. D., Mun, H. J., Cha, B. J. and Park, S. Y., Prevalence of Musculoskeletal Symptom in Rural Farmers, The Journal of Rheumatology Health, 8(1), 86-108, 2001.

Oh, S. B., Ha, W. H., Park, S. H. and Lee, K. H., "Improvement of Ergonomic Risk Factor of mushroom harvesting", Proceedings of 2008 Spring Conference of Ergonomics Society of Korea, pp.618 $-621,2008$.

Rural Resource Development Institute, Work safety measures considering physical characteristics of elderly farmers, 2006.

Seo, J. H., Kang, B. S., Lee, K. S., Yun, S. H., Hwang, T. Y. and Park, J. S., Prevalence and Related Factors of Knee Osteoarthritis in Rural Women, Korean Journal of Rural Medicine, 30(2), 167-182, 2005.

Sung, N. J., Sakong, J. and Chung, J. H., Musculoskeletal Disorders and Related Factors of Symphony Orchestra Players, Korean Journal of Occupational and Environmental Medicine, 12(1), 48-58, 2000.

Toren, A., Oberg, K., Lembke, B., Enlund, K. and Rask-Anderson, A., Tractor-driving hours and their relation to self-reported low-back and hip symptoms, Applied Ergonomics, 33(2), 139-146, 2002.

Van wely, P., Design and Disease, Applied ergonomics, 5(1), 262-269, 1970.

Yang, Y. A., The Responding Strategies of Musculoskeletal Disease in Aging Society, Journal of the Ergonomics Society of Korea, 29(4), 505-511, 2010.

\section{Author listings}

Soo-Jin Lee: sjlee@hanyang.ac.kr

Highest degree: M.D., PhD., Department of Preventive Medicine, Catholic University

Position title: Associated professor, Department of occupational and environmental medicine, Hanyang University

Areas of interest: Agricultural medicine, Work-related disase

Hwan Jin Park: ppakans@gmail.com

Highest degree: M.B., College of medicine, Hanyang University Position title: Resident, Department of occupational and environmental medicine, Hanyang University Hospital

Areas of interest: Work-related disease

Date Received : 2011-06-22

Date Revised :2011-07-26

Date Accepted : 2011-07-27 